ECONOMICS

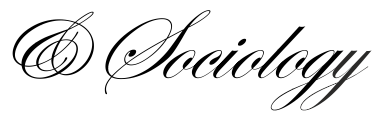

Mangani, K.S., Syaukat, Y., Arifin, B., \& Tambunan, M. (2019). The role of branchless banking in performance of households' micro and small enterprises: The evidence from Indonesia. Economics and Sociology, 12(3), 114-131. doi:10.14254/2071-789X.2019/12-3/8

\title{
THE ROLE OF BRANCHLESS BANKING IN PERFORMANCE OF HOUSEHOLDS' MICRO AND SMALL ENTERPRISES: THE EVIDENCE FROM INDONESIA
}

\begin{abstract}
Ktut Silvanita Mangani, Universitas Kristen Indonesia, Jakarta, Indonesia

E-mail:ktut.silvanita@uki.ac.id
\end{abstract}

Yusman Syaukat, Bogor Agricultural University, Bogor, Indonesia

E-mail:ysyaukat@gmail.com

\section{Bustanul Arifin, Universitas Lampung, Lampung, Indonesia \\ E-mail:barifin@uwalumni.com}

\author{
Mangara Tambunan, \\ Bogor Agricultural University, \\ Bogor, Indonesia \\ E-mail: \\ mangara43tambunan@yahoo.com
}

Received: March, 2019

1st Revision: June, 2019

Accepted: September, 2019

DOI: $10.14254 / 2071-$

789X.2019/12-3/8

JEL Classification: D13, O12, G20
ABSTRACT In Indonesia, branchless banking (BB) for lowincome communities is a new financial channel to create a financial system accessible to all levels of society. This research aims to investigate how to develop BB programs to improve the performance of households' micro and small enterprises (MSEs) in rural areas. The data was collected from 97 MSEs who conducted financial transactions at BB agents. For a case study, as many as 32 agents out of $360 \mathrm{BB}$ agents in Bogor District, West Java, Indonesia were chosen purposively from 13 sub-districts. Then, 97 MSEs were chosen with the experience of conducting transactions through $\mathrm{BB}$ agents. The study analyzes the household economic behavior using the model of a simultaneous structural equation, that has not been discussed in prior literature on Branchless Banking studies. The study has found that an increase in the value of financial transactions and investment variables have a positive impact with larger magnitudes on the production and other endogenous variables than an increase of those variables independently. However, the impact on household savings is small. The results imply that the development of MSEs through BB programs is not enough by only providing the speed and ease of financial transactions through the presence of $\mathrm{BB}$ agents in rural areas that are close to local businesses. Capacity building by increasing the investment value of micro and small enterprises becomes a factor driving the success of $\mathrm{BB}$ programs.

Keywords: branchless banking, financial inclusion, household economic behaviour, micro and small enterprise, simultaneous equation model.

\section{Introduction}

Financial sector is a parent of the development process as it makes financial services and products accessible to everyone. This is one of the ways to overcome poverty (DemirgucKunt \& Levine, 2008). Equitable distribution of financial services will create new and rapid sources of economic growth, thus leading to equitable growth (Sanjaya, 2014; Jain, 2015). 
Bank as a provider of liquidity allows investments in more productive assets that can improve the efficiency of capital accumulation and economic growth. However, the World Bank survey as of 2014 showed that only about $50 \%$ of the world's adult population has access to formal financial institutions (World Bank, 2014). One of the problems is low spread of formal financial institutions, such as banks, to remote rural areas.

The research by Wilis et al. (2001) explains that information and communication technologies have allowed some bank institutions redevelop their branch networks in a more differentiated manner, targeting the demands of different customers residing in different places. McKay and Pickens (2010) explained that one form of a potential financial delivery channel to serve the 'unbanked' people who are mostly living in rural areas is branchless banking (BB). $\mathrm{BB}$ is a banking service provided by financial service providers to customers without having to come to a bank office; banks bring their services closer to customers in remote areas. To that end, bank uses a third party or an agent as an extension of bank services onto rural areas.

There are three kinds of BB models, differentiated basing on the principal or business owner of a BB service provider (Mas, 2009; Davidson, 2011). The first model is BB run by a mobile network operator (MNO). MNO has an advantage of having a strong distribution channel and many customers, who are generally unfamiliar with banks as such. Such people are sometimes called "unbanked" people. Operators know how to build networks of independent retail agents and can leverage these networks to serve as cash-in/cash-out points for mobile money service. But the model has a weakness because it does not have the ability to run the core banking process. An example of this model is M-PESA which is very popular in Kenya and Tanzania. M-PESA is run by the Safaricom network operators, using applications in cell phones. Other examples are Smart Money and G-Cash in the Philippines, as well as Orange, Zain, and MTN in Africa.

The second model is a bank-led model in which the principal is the bank institution. Banks have licenses and are subject to supervision of banking authorities, they also have risk management systems and advanced fraud detection skills. Banks, particularly those with branches in rural areas, are ideally situated to support agent liquidity. However, the bank-led model has some disadvantages too: banks' profits are based on fluctuating interest rates and cross-selling products which reduce the chances for the poor, as well as lead to high infrastructure costs for both front-end and back-end offices. Banking correspondents in Brazil, Chile, Colombia, and Peru practice this bank-led model. They use networks of Point Of Sale based agents.

The third one is the BB model run by a third party, namely a mobile payment provider. This model encourages interoperability between banks and telecommunications companies, as well as other willing partners, such as the organizations serving the poor. But the disadvantage of this model is that they may not have much power over larger banks and telcos. The examples of this model are WIZZIT in South Africa, Net U.E.P.S. in Africa, and EKO in India. Countries practicing branchless banking are shown in Table 1.

In Indonesia, Branchless Banking program, especially for low-income communities, is a new form of a financial delivery channel using technology. The goals are to promote economic growth through poverty alleviation, income distribution, and financial system stability by creating a financial system accessible to all levels of the society (BI, 2014). Through BB program, people in remote areas become closer to banks in conducting their financial transactions, so banks have a record of their financial condition which will make it easier for the banks to channel credit for community productive activities. Financial Services Authority (OJK) calls its program "Layanan Keuangan Tanpa Kantor Dalam Rangka Keuangan Inklusif " - the Non-Office Financial Services in the Framework of Inclusive Finance - or "Laku Pandai". The objective of this program is to provide simple, understandable and appropriate financial products to meet the needs of those who are not able to reach current financial services, 
and with the increasing number of members of various community groups in different parts of Indonesia using financial services. Then the economy of the community is expected to be more smoothly so that it can promote economic growth and equitable development among the regions in Indonesia, especially between villages and cities (OJK, 2015).

Table 1. Countries that practice Branchless Banking

\begin{tabular}{lll}
\hline Country & Provider & Model \\
\hline Afghanistan & Roshan (mobile operator) & M-banking \\
\hline Chile & Banco Estado (bank) & Card-based \\
\hline Colombia & Banco Caja Social (bank) & Card-based \\
\hline DR Congo & Celpay (bank) & M-banking \\
\hline India & SKS Microfinance (MFI) & M-banking \\
& State Bank of India (bank) & M-banking \\
\hline Kenya & Safaricom (mobile operator) & M-banking \\
& Equity Bank (bank) & M-banking \\
\hline Malawi & Opportunity International (bank) & Card-based \\
& First Merchant Bank (bank) & Card-based \\
\hline Mexico & Banamex (bank) & Card-based \\
\hline Mongolia & XacBank (bank) & M-banking \\
\hline Pakistan & Tameer Bank (bank) & M-banking \\
\hline Peru & Banco de Crédito (bank) & Card-based \\
\hline Philippines & SMART (mobile operator) & M-banking \\
& GXI (mobile operator) & M-banking \\
\hline Russia & Tavrichesky Bank (bank) & M-banking \\
\hline Senegal & Ferlo (third-party) & Card-based \\
\hline South Africa & MTN Banking (bank-mobile operator joint venture) & M-banking \\
& WIZZIT (third-party) & M-banking \\
\hline Tanzania & Vodacom (mobile operator) & M-banking \\
\hline Uganda & Uganda Microfinance Ltd. (MFI) & Card-based \\
\hline
\end{tabular}

*) In this table, a mobile operator is referred to as "m-banking"

Source: Ivatury (2008)

Through the Branchless Banking program in remote areas, then there will be an accumulation and flow of funds, thereby increasing the production capacity of the community and overcome poverty in those areas. However, since the implementation of the program is still early; started since the issuance of the Financial Services Authority Regulation (POJK) Number 19 / POJK.03 / 2014, the secondary data of program implementation at the household level was not found yet. Therefore, this study aims to analyze the implementation of the BB program at the household level of business actors around the agent, i.e. to analyze how the financial transactions have a potential impact to improve the production capabilities with the availability of financial services at their places.

Previous research on Branchless Banking (i.e. mobile-banking) mostly performed analysis on the demand side, namely the acceptance of information technology (Yuwono, 2017; Permadi, 2017; Shadikin, 2017; Chuchuen, 2016; Phanthanukitithaworn et al., 2015; Montazemi \& Saremi, 2015; Shaikh \& Karjaluoto, 2015; Siddik et al., 2014). Other studies did analysis on the supply side but focus on the individual unit as well as bank institutions as Branchless Banking program provider (Frani, 2017; Secioktaviany, 2016; Khanan \& Pujiono, 2016; Wibowo, 2013). This study focuses on the supply side and examines the household economic behaviours by using Simultaneous Equations Model (SEM), that have not been discussed in prior literature on Branchless Banking studies. The model then used to analyze the existence of households' micro and small business as the program target group involved in the 
BB program, in terms of production activities and financial transactions, especially to analyze the potential of economic development of target groups related to the development of $\mathrm{BB}$ program.

\section{Conceptual Framework}

The decisions on productive economic activities include input use decisions and marketing decisions. The decisions on the use of input consist of capital use (investment), use of labor both family labor and lease labor, and use of other raw materials. Household of business actors has manpower that can be allocated both in household business activities and activities outside the household (as leased labor). On the other hand, the decision to sell the output in the market is based on the desired earnings and the fulfilment of the household consumption needs. The decisions on household consumption include food and non-food consumption, as well as investment expenditure on human resources and health investment expenditures. Furthermore, the financial transaction decisions at the BB Agents include cash deposits (savings), cash withdrawals, transfers, online bill payments and pay some obligations, as well as borrowing money (credits) that can be obtained through BB Agents or family or money lender.

The decision of business households in production activities, financial transactions, or other related household decisions is also influenced by the presence of BB Agents as the spearhead in a BB system. The presence of BB Agents in the midst of productive business activities is expected to boost production by supporting the ease of financial transactions and the availability of money close to the business. These conditions are expected to increase the output of their business thus increasing acceptance and creating more financial transactions to the Agent. Thus, the goal of a BB program to reach broad of 'unbanked' and 'underbanked' communities, create production growth, and expand the network and facility of strong financial services in the rural area will be achieved.

However, based on an observation conducted in a preliminary study before doing the true research, the data found in the institution level, i.e. the financial service authority and the bank institutions as BB program executors was the data accumulation of the transactions. The secondary data on production activities and transactions from each customer who conducted transactions through agents was not yet found. In the households level as the sample of this study, it was not found sufficient records regarding production activities; their records were very simple and inconsistent. The characteristics of production decisions of households micro and small business in rural areas are similar to the farm households in which one economic decision will depend on other economic decisions, both internal and external. Therefore, the households economic behaviour model used in this study is a Simultaneous Equation Model/SEM (Bagi and Singh, 1974). The economic decisions are categorized into six decisions: (a) production, (b) consumption, (c) Marketed surplus, (d) labor usage, (e) investment, and (6) credit.

The model specification of the production activity and its relation to the financial transaction activities in the branchless banking program is shown in the following equations:

$$
\begin{aligned}
& \mathrm{Q}=\mathrm{a}_{0}+\mathrm{a}_{1} \mathrm{INV}+\mathrm{a}_{2} \mathrm{TK}+\mathrm{a}_{3} \mathrm{P}+\mathrm{a}_{4} \mathrm{VCOST}+\mathrm{a}_{5} \mathrm{TCONS}+\mu_{1} \\
& \mathrm{INV}=\mathrm{b}_{0}+\mathrm{b}_{1} \mathrm{Cr}+\mathrm{b}_{2} \mathrm{SAV}+\mathrm{b}_{3} \mathrm{PFIT}+\mathrm{b}_{4} \mathrm{FCOST}+\mu_{2} \\
& \mathrm{TKK}=\mathrm{c}_{0}+\mathrm{c}_{1} \mathrm{AKK}+\mathrm{c}_{2} \mathrm{~W}+\mathrm{c}_{3} \mathrm{TKL}+\mathrm{c}_{4} \mathrm{PFIT}+\mu_{3} \\
& \mathrm{TKL}=\mathrm{d}_{0}+\mathrm{d}_{1} \mathrm{~W}+\mathrm{d}_{2} \mathrm{TKK}+\mathrm{d}_{3} \mathrm{P}+\mathrm{d}_{4} \mathrm{MS}+\mu_{4} \\
& \mathrm{TK}=\mathrm{TKK}+\mathrm{TKL} \\
& \mathrm{MS}=\mathrm{e}_{0}+\mathrm{e}_{1} \mathrm{P}+\mathrm{e}_{2} \mathrm{Q}+\mathrm{e}_{3} \mathrm{SU}+\mu_{5} \\
& \mathrm{SU}=\mathrm{f}_{0}+\mathrm{f}_{1} \mathrm{INV}+\mathrm{f}_{2} \mathrm{Cr}+\mu_{6}
\end{aligned}
$$




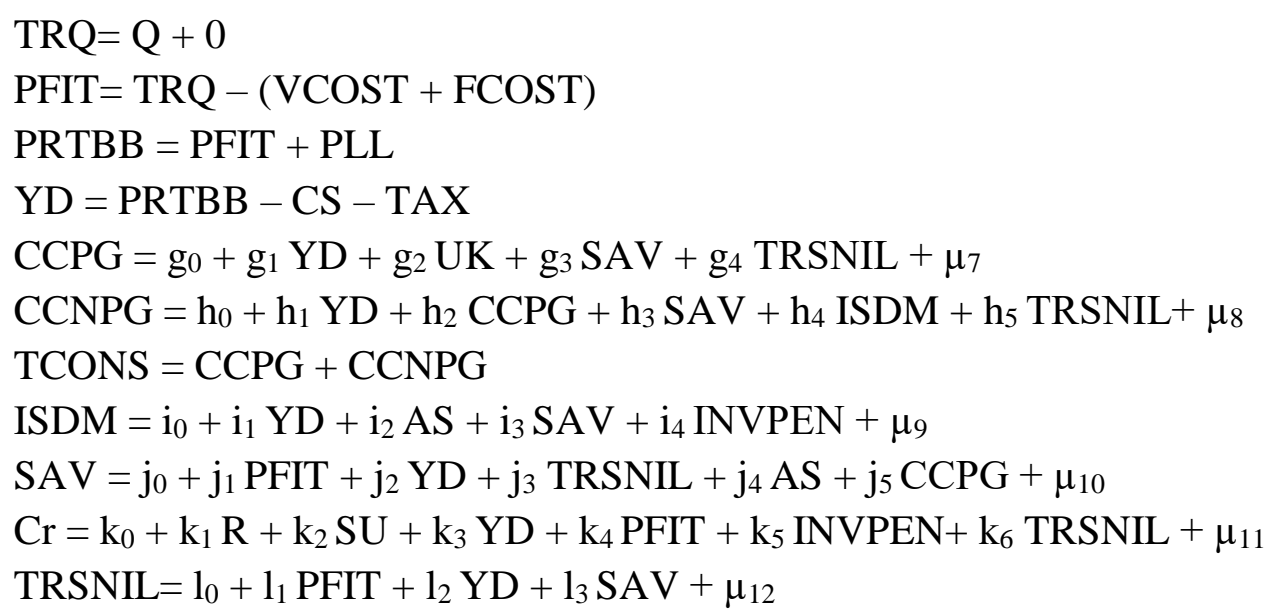

Note. Definition of the variables is presented in the appendix.

The expected sign of the parameters (hypothesis) of the equations are: $a_{1}, a_{2}, a_{3}, a_{4}, a_{5}$; $b_{1}, b_{2}, b_{3}, b_{4} ; c_{1}, c_{2}, c_{4} ; d_{3}, d_{4} ; e_{1}, e_{2}, e_{3} ; f_{1}, f_{2} ; g_{1}, g_{2}, g_{4} ; h_{1}, h_{3}, h_{4}, h_{5} ; i_{1}, i_{2}, i_{4} ; j_{1}, j_{2}, j_{3}, j_{4} ; k_{2}, k_{3}$, $\mathrm{k}_{4}, \mathrm{k}_{5}, \mathrm{k}_{6} ; \mathrm{l}_{1}, \mathrm{l}_{2}, \mathrm{l}_{3}>0$, dan $\mathrm{c}_{3}, \mathrm{~d}_{1}, \mathrm{~d}_{2}, \mathrm{~g}_{3}, \mathrm{~h}_{2}, \mathrm{i}_{3}, \mathrm{j}_{5}, \mathrm{k}_{1}<0$.

\section{Methodological approach}

In line with the research objective namely, to analyze the role of the Branchless Banking program, i.e. the role of BB Agent on the performance of micro and small business households, then this study was conducted only on the small micro-business households that have utilized BB Agents in their financial transactions. The research was conducted at Bank ' $\mathrm{X}$ ' (one of the national bank in Indonesia) that had implemented the Branchless Banking program.

The sample selection was done in stages by first determining the location of the study as a case study of the implementation of Branchless Banking programs in remote areas, namely Bogor Regency, West Java Province. Out of 40 sub-districts in Bogor District, there are 13 subdistricts were selected purposively, namely Jasinga, Cibungbulang, Pamijahan, Dramaga, Ciomas, BojongGede, Cibinong, Taman Sari, Ciawi, Babakan Madang, Sukaraja, Klapanunggal, as well as Tanah Sereal and North Bogor sub-districts at the outskirt of Bogor City (Figure 1).

Furthermore, from each sub-district was selected some BB Agents.As an extension of limited banking services in the rural areas, the tasks and functions of BB Agents are homogeneous. Therefore, BB Agents were chosen purposively, i.e. those that have a relatively high number of financial transactionsas as one of the criteria of the success of Branchless Banking program. From those agents, then samples of micro and small business households were selected, i.e. those who have utilized BB Agent in their financial transactions. The data was collected in November to December 2016. 


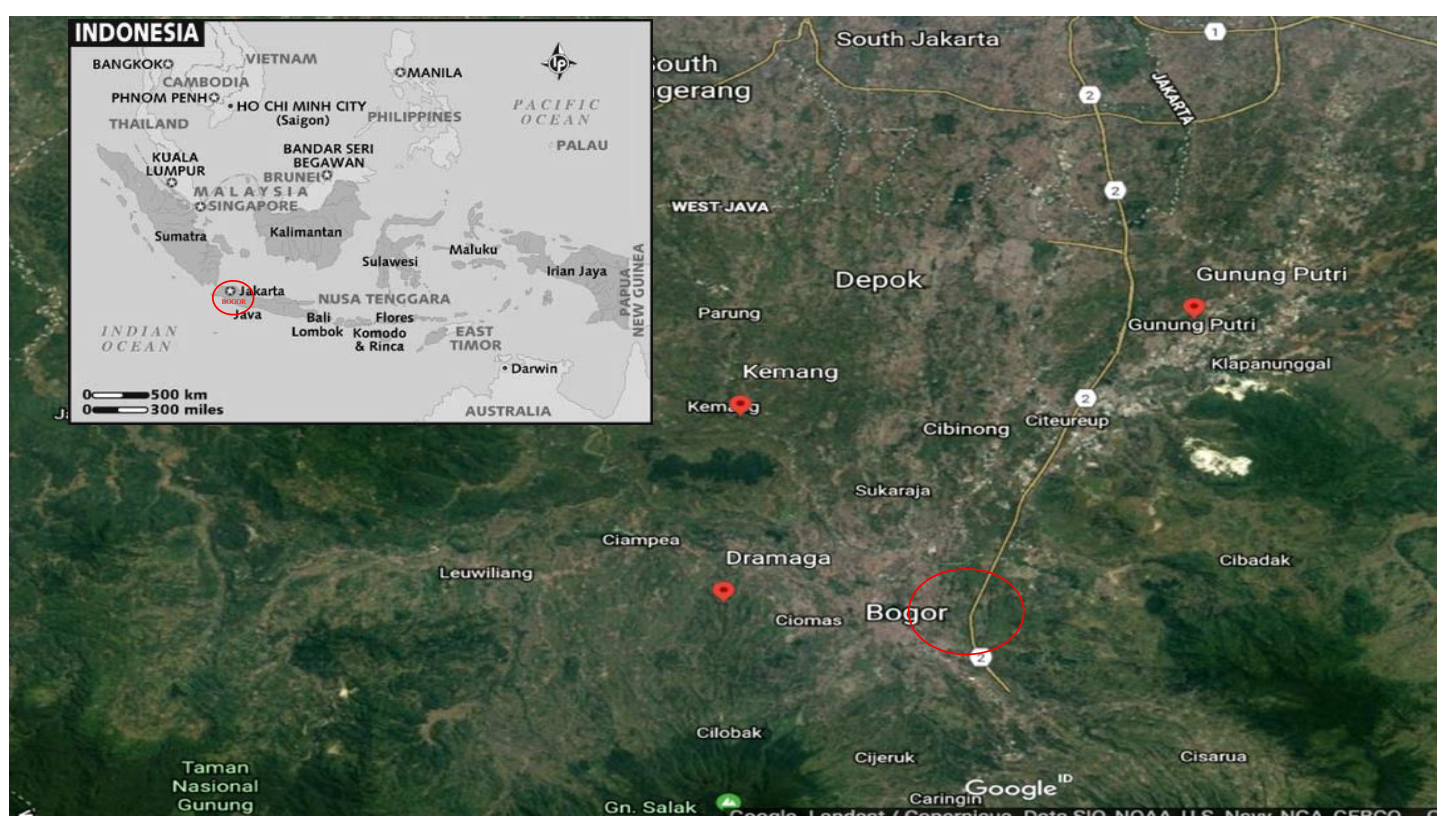

Figure 1. Map of the study area in Bogor District, West Java, Indonesia.

Source: Google earth.

Before doing an estimation, the model is identified using an 'order condition' (Koutsoyiannis, 1977). The model is said to be identifiable when the sum of all (endogenous and exogenous) variables that are not present in the equation but contained in other equations $(\mathrm{K}-\mathrm{M})$ at least equal to the sum of all endogenous variables $(\mathrm{G})$ minus one, $[(\mathrm{K}-\mathrm{M}) \geq(\mathrm{G}-$ 1)]. Furthermore, the parameters are estimated using 2SLS (Two Stage Least Squares) method.

Prior to the simulation, conducted a validation using Newton method with Simlin procedure, to check whether the estimated model reflects the reality and fulfill the requirements of the model application objectives (Sinaga, 2011). The statistics of fit criteria used are root mean squares percent error (RMPSE) and statistic value of U-Theil. Furthermore, the scenario of simulation will be conducted toward (1) The change in transaction value, (2) The change in investment value, and (3) The combination change of investment and transaction values.The change in transaction value aims to determine the impact of BB program development on the economic behaviors of the business household in rural area.The change in investment value is aimed to find out the impact of the increase of household business capacity to the demand of credit as one of BB program instrument, as well as its impact on other variables of the household economic behaviors. The combination of changes aims to compare the impact of the development of the BB program on the economic development of the target group, without and with the encouragement of business capacity development. Thus, it can be obtained the best scenario for the development of BB programs for micro-small business in the rural area.

\section{Conducting research and results}

This study aims to explore and analyze the implementation of BB program in remote areas, namely rural areas, by choosing Bogor District as a case-study, a region in West Java province of Indonesia. Bogor District is chosen as a remote area assumed to be a region with relatively high successful rate compared to other regions in Indonesia in implementing the program as a remote area located adjacent to Jakarta city, the capital city of Indonesia.

As an extension of a bank office in a rural area providing limited banking services, the duties and functions of BB Agents are homogeneous, i.e. providing limited banking services to customers, such as checking balance accounts, savings, withdrawals, bill payments, voucher 
sales and top-up mobile phone credit, as well as selling electricity vouchers. Therefore, the BB Agent was chosen purposively from 13 sub-districts out of 40 sub-districts in Bogor District.

As of August 2016, there were 360 BB Agents of Bank ' $X$ ' in Bogor District out of 5,514 BB Agents in West Java province. As many as32 BB Agents from 27 villages in Bogor District were chosen with the assistance of the Bank ' $\mathrm{X}$ ' Unit in each of the selected sub-districts, namely agents who were considered quite active. Furthermore, samples of micro and small busniess household around the agents who have ever conducted financial transaction through a agent. The data was collected in November until December 2016.

Although there were quite a number of micro-small businesses around the BB Agent, however still few of them who conducted their financial transactions through BB Agent.There are only two or three of small and micro household respondents who have ever conducted financial transactions at BB Agent. Most of BB Agent customers are housewives or those who do not have productive business activities, namely those who are not the target respondents of this study. Thus, there are only 97 micro and small business households that have conducted financial transactions in $32 \mathrm{BB}$ Agents chosen.

The data was collected using questionnaires, namely data related to production activities of micro-small household respondents and financial transaction activities carried out through BB Agent. The data was then processed using SPSS software. After checking for 'order condition'--wherein $(\mathrm{K}-\mathrm{M}) \geq(\mathrm{G}-1)$ which proved that the model is 'over identified'-- then the method of 2SLS (2 stage least square) was applied to estimates the parameters.

The business activities of households respondents mostly are kiosks selling basic daily necessities, food stalls and other kiosks that sell various types of goods, such as kiosks selling gallon water refill, cell phone \& electricity vouchers, peddlers, craftsmen, as well as kiosk provide business services such as photocopy services, motorcycle workshops, etc. However, the distribution of the business activity is uneven, and the size of the business varies greatly, as shown in Table 2.

Table 2. Types of respondent business activities

\begin{tabular}{llll}
\hline $\begin{array}{l}\text { Types of } \\
\text { business }\end{array}$ & Activity & $\begin{array}{l}\text { No. of } \\
\text { Respd }\end{array}$ & Percent \\
\hline $\begin{array}{l}\text { Staple goods } \\
\text { stalls }\end{array}$ & Stalls selling basic daily needs. & 17 & 17.52 \\
\hline Food stalls & $\begin{array}{l}\text { Stalls selling ready food such as 'gado-gado' (Indonesian } \\
\text { local food, consisting of vegetables with peanut sauce), } \\
\text { meatball, coffee, noodles, fried chicken, etc. }\end{array}$ & 12 & 12.37 \\
\hline Kiosk & $\begin{array}{l}\text { Kiosks selling gallon water refill, cell phone\&electricity } \\
\text { credit vouchers, electrical materials, paints, eggs, DVD, } \\
\text { cakes, internet game services, etc. }\end{array}$ & 35 & 36.08 \\
\hline Peddlers & Peddlers sell: banana, crackers, 'putu' cake,'siomay' & 7 & 7.22 \\
\hline Craftsmen & Shoes maker, wooden frame maker, fiber glass & 5 & 5.15 \\
\hline $\begin{array}{l}\text { Services } \\
\text { business }\end{array}$ & $\begin{array}{l}\text { Photocopy, motorcycle workshop, tailor, barber, beauty } \\
\text { salon, primary school, money lender, etc. }\end{array}$ & 21 & 21.65 \\
\hline
\end{tabular}

Sources: own data

Types of financial transactions carried out by business households shown in Table 3. are mostly the transactions to pay electricity bills (45.59\%). The transfer transactions $(27.13 \%)$ were generally carried out by entrepreneurs (generally peddlers dan money lenders) who come from other regions; they send their income to family members who live in different areas. Other types of transactions that are also quite widely conducted by business households through BB 
agents are transactions for cell-phone credit top-up (15.98\%), while cash deposit transactions (savings) and cash withdrawals are rarely done (11.30\%).The data shows that the types of financial transactions carried out by business households in BB agents are transactions that are not directly related to their business activities but are more related to non-food consumption expenditure. The data also explains that the number of transactions conducted by business households through BB agents is low, i.e. 28 transactions in average per household per year or two to three transactions per month.

Table 3. Respondents financial transactions through BB agent

\begin{tabular}{lcc}
\hline Type of Transaction & Frequency/year & Percent \\
\hline Cash deposits (Savings) & 187 & 6.46 \\
\hline Cash Withdrawals & 144 & 4.84 \\
\hline Transfers & 576 & 27.13 \\
\hline Electricity payment (pre/post-paid) & 1,346 & 45.59 \\
\hline Cell-phonecredittop-up & 422 & 15.98 \\
\hline Credit proposal & 0 & 0.00 \\
\hline Average transaction/year & $27.59 \sim 28$ & \\
\hline Average transaction/month & 2.33 & \\
\hline
\end{tabular}

Source: Own data

In addition, the expected credit proposals conducted through BB agent has not existed. Besides due to certain matters that are not included in the focus of this study, those conditions can be caused by the low of the numbers, type, and value of the financial transactions that conducted by the customers through BB agent, so the bank does not have enough information about their eligibility to receive credit.The existing credits, generally in the form of loans obtained directly from the bank office or lease loans for motorcycle purchases, as well as loans from family or loans to purchase household items paid by installments. Thus, the role of BB agents related to credit, still limited as a means of transfer for installment payments to leasing companies. Meanwhile, bank credit installment payments are done automatically by debiting customer accounts.

\subsection{Model estimation and validation}

Model estimation is done through several iterations until the parameter mark in the model does not conflict with the theory. Therefore, the resulting structural equation model has changed from the specifications of the previous model. The descriptive statistics of the structural equation model is presented in the Table 4.

The estimation results explain that all the F-test analysis are significant $(\operatorname{Pr} \mathrm{F}<0.0001)$, which means that all explanatory variables in each structural equation were simultaneously affecting its endogenous variable. The results of the determination coefficient $\left(\mathrm{R}^{2}\right)$ vary, ranging from $27 \%-99.96 \%$. 
Table 4. Means and standard deviation

\begin{tabular}{|c|c|c|c|c|c|}
\hline Variables & Mean & Std Deviation & Variables & Mean & Std Deviation \\
\hline Intercept & 1.0000 & 0 & TKK & 714.0 & 287.7 \\
\hline PS & 0.000902 & 0.00232 & TKL & 339.8 & 1258.9 \\
\hline VCOST & $1.8177 \mathrm{E}+08$ & $2.1302 \mathrm{E}+08$ & TK & 1053.7 & 1227.4 \\
\hline FCOST & 5038638 & 22331702 & MS & $2.7818 \mathrm{E}+08$ & $2.9297 \mathrm{E}+08$ \\
\hline AKK & 2.7113 & 0.9996 & SU & $3.2902 \mathrm{E}+08$ & $3.7848 \mathrm{E}+08$ \\
\hline UK & 3.5773 & 1.059 & TRQ & $2.8213 \mathrm{E}+08$ & $2.9344 \mathrm{E}+08$ \\
\hline $\mathrm{W}$ & 680001 & 1361925 & TBQ & $1.8681 \mathrm{E}+08$ & $2.1289 \mathrm{E}+08$ \\
\hline TBB & $1.4717 \mathrm{E}+08$ & 10954125 & PFIT & 95327186 & $1.18 \mathrm{E}+08$ \\
\hline $\mathrm{CS}$ & 4058753 & 5914511 & TRTBB & $1.1277 \mathrm{E}+08$ & $1.1963 \mathrm{E}+08$ \\
\hline TAX & 963680 & 1335758 & YD & $1.0775 \mathrm{E}+08$ & $1.1948 \mathrm{E}+08$ \\
\hline AS & 1.1474 & 0.9752 & TCONS & 26460608 & 18159068 \\
\hline PLL & 17447341 & 26626933 & CCPG & 14115159 & 6429130 \\
\hline $\mathrm{R}$ & 7.7577 & 5.5571 & CCNPG & 12345449 & 15458293 \\
\hline CILCR & 1064258 & 1884898 & ISDM & 5297821 & 7219269 \\
\hline $\mathrm{P}$ & 61444.8 & 123145 & SAV & 24484227 & 34627054 \\
\hline INVPEN & 4566192 & 7145767 & $\mathrm{CR}$ & $1.2942 \mathrm{E}+08$ & $2.3656 \mathrm{E}+08$ \\
\hline $\mathrm{Q}$ & $2.8213 \mathrm{E}+08$ & $2.9344 \mathrm{E}+08$ & TRSNIL & 9673186 & 14236976 \\
\hline INV & 47131442 & $2.2408 \mathrm{E}+08$ & & & \\
\hline
\end{tabular}

Source: own compilation

The economic models of the business household are as follows:

$\mathrm{Q}=-1.279 \mathrm{E} 7+0.126 \mathrm{INV}^{*}+21717.42 \mathrm{TK}^{* * *}+1.105 \mathrm{E} 10 \quad \mathrm{PS}^{*}+1.239 \mathrm{VCOST}^{*}+1.169$ TCONS $^{* * *}$

$\mathrm{INV}=-2.375 \mathrm{E} 7+0.006 \mathrm{PFIT}+10.0038 \mathrm{FCOST}^{*}+4842465 \mathrm{UK}^{* *}+7269.94 \mathrm{TK}^{* * *}$ $0.41 \mathrm{CCNPG}^{* * *}$

$\mathrm{TKK}=245.9959+6.177 \mathrm{E}-6 \mathrm{~W}+170.907 \mathrm{AKK}^{*}-0.13936 \mathrm{TKL}^{*}+5.007 \mathrm{E}-7 \mathrm{PFIT}$

$\mathrm{TKL}=765.4539-0.00012 \mathrm{~W}^{* *}+1.391 \mathrm{E}-6 \mathrm{MS}^{*}-1.31868 \mathrm{TKK}^{*}+0.003410 \mathrm{P}^{*}$

$\mathrm{MS}=-3996061+5.3277 \mathrm{E} \mathrm{PS}^{*}+0.001500 \mathrm{SU}+0.996693 \mathrm{Q}^{*}$

$\mathrm{SU}=1.0958 \mathrm{E} 8+1.077970 \mathrm{INV}^{*}+1.3029887 \mathrm{CR}^{*}$

$\mathrm{CCPG}=7292784+0.051134 \mathrm{PRTBB}^{*}+2208236 \mathrm{AS}^{*}-0.06036 \mathrm{SAV}^{*}$

$\mathrm{CCNPG}=936107+0.0434 \mathrm{YD}^{* *}-0.9327 \mathrm{CCPG}^{* *}+1.9275 \mathrm{SDM}^{*}+0.1303 \mathrm{TRSNIL}^{*}$

$\mathrm{ISDM}=492573.8+0.00113 \mathrm{YD}^{*}+234093 \mathrm{AS}^{*}-0.0056 \mathrm{SAV}^{*}+0.9969 \mathrm{INVPEN}^{*}$

$\mathrm{SAV}=33284844+0.227437 \mathrm{YD}^{*}+22370941 \mathrm{AS}^{*}-4.17823 \mathrm{CCPG}^{*}$

$\mathrm{CR}=-5.868 \mathrm{E} 7+0.14738 \mathrm{SU}^{*}+1.84079 \mathrm{PFIT}^{*}-4.9299 \mathrm{CCNPG}^{*}+5.4736 \mathrm{INVPEN}^{* *}$

Note: Significant level: ${ }^{*}=\alpha / 2=5 \% ;{ }^{* *}=\alpha / 2=10 \% ;{ }^{* * *}=\alpha / 2=15 \%$

Prior to simulation, performed a model validation using RMPSE and U-Theil criteria as presented in Table 5.

The results show that the model reflects the true state of the households's economic behaviours in a BB program. Therefore, it can be used for simulation purposes to analyze the impact of changing of the important economic variables on the household business decisions. 
Table 5. Validation results of the model

\begin{tabular}{|c|c|c|c|}
\hline \multirow{2}{*}{\multicolumn{2}{|c|}{ Structural Variable }} & \multicolumn{2}{|c|}{ StatisticValidation } \\
\hline & & RMSPE & U-Theil \\
\hline $\mathrm{Q}$ & Production value & 47.816 & 0.1180 \\
\hline INV & Investment & 2272.900 & 0.0504 \\
\hline TKK & Family labor & 36.930 & 0.1288 \\
\hline TKL & Non-family labor & 49824.800 & 0.4893 \\
\hline TK & Total labor & 130.400 & 0.3689 \\
\hline MS & Marketed surplus & 48.006 & 0.1195 \\
\hline SU & Business size & 114.500 & 0.1710 \\
\hline TRQ & Total revenue of Production & 47.816 & 0.1180 \\
\hline PFIT & Profit & 305.300 & 0.3476 \\
\hline PRTBB & Total revenue of households & 132.000 & 0.3152 \\
\hline YD & Disposable income & 148.400 & 0.3236 \\
\hline TCONS & Total consumption & 30.674 & 0.1298 \\
\hline $\mathrm{CCPG}$ & Food consumption & 38.225 & 0.1644 \\
\hline CCNPG & Non-food consumption & 86.080 & 0.1823 \\
\hline ISDM & HR investment & 27.359 & 0.0093 \\
\hline SAV & Saving & 650.300 & 0.4138 \\
\hline $\mathrm{CR}$ & Credit & 3.848E9 & 0.3243 \\
\hline
\end{tabular}

Source: Own compilation

\subsection{Simulation-1: The impact of an increase in transaction value}

The presence of $\mathrm{BB}$ agents closes to business activity in the rural will encourage business households to deposit the money from their business into bank accounts through the BB agents, rather than storing it under a 'pillow'. They also can arrange their money withdrawal as much as they need. On the other hand, the location of a bank office located away from their residence or business location will encourage them to delay saving or encouraging them to withdraw funds in greater amounts than necessary to offset transportation costs, lost time, and other expenses. Therefore, transactions by the business households on BB agents, especially savings and cash withdrawal transactions, can be a signal of production activity.

The value of financial transactions conducted by business households on BB agents could indicate the level of trust of the business households to the agent and may become a signal of the success of the program. The higher the value of the transaction can be measured by the higher of the frequency of transaction. The data described in Table 16shows that the frequency of transactions by the households at $\mathrm{BB}$ agents is low, therefore the value of transactions (TRSNIL) is also low. The average frequency of transactions is 28 per year per households or two to three transactions per month per households. To achieve the success of BB program, it is necessary to increase the frequency of transactions in a large percentage, so that it will increase the value of transaction. Therefore, in this study, the scenarios chosen for the increase in the value of transactions is $100 \%$. The simulation result is presented in Table 6 .

The results show that the development of the BB program encourages production through consumption expenditure (CCNPG, TCON), but does not affect the development of business capacity (investment/INV). The results are in line with the conditions in the field, that most business actors conducted a financial transaction at BB Agents for payment transactions such as pay for electricity bill (pre/post-paid) and to top-up a cellular phone credit, as well as transfer their money to another account (see Table 3). The changes in savings transaction (SAV) which related to productive activities is very low. 
Table 6. The impact of an increase in transaction value (TRSNIL)

\begin{tabular}{llrr}
\hline \multirow{2}{*}{ Endogen Variable } & \multicolumn{2}{c}{$100 \%$ TRSNIL } \\
\cline { 2 - 4 } 1. & Production (Q) & $1,540,000$ & 0.55 \\
\hline 2. & Investment (INV) & $(490,341)$ & -1.04 \\
\hline 3. & Family Labor (TKK) & 0.60 & 0.08 \\
\hline 4. & Non-Family Labor (TKL) & 1.40 & 0.41 \\
\hline 5. & Total Labor (TK) & 2.00 & 0.19 \\
\hline 6. & Marketed Surplus (MS) & $1,540,000$ & 0.55 \\
\hline 7. & Business Size (SU) & $(640,000)$ & -0.17 \\
\hline 8. & Total Revenue of Production (TRQ) & $1,540,000$ & 0.55 \\
\hline 9. & Profit (PFIT) & $1,538,282$ & 1.61 \\
\hline 10. & Total Revenue of BB Households (PRTBB) & $1,540,000$ & 1.37 \\
\hline 11. & Disposable Income (YD) & $1,540,000$ & 1.43 \\
\hline 12. & Total Consumption (TCONS) & $1,332,504$ & 5.04 \\
\hline 13. & Food Consumption (CCPG) & 76,946 & 0.55 \\
\hline 14. & Non-Food Consumption (CCNPG) & $1,255,557$ & 10.17 \\
\hline 15. & HR Investment (ISDM) & 1,584 & 0.03 \\
\hline 16. & Saving (SAV) & 28,361 & 0.12 \\
\hline 17. & Credit (CR) & $(80,000)$ & -0.05 \\
\hline
\end{tabular}

\section{Source: Own compilation}

The results also explain that the increase in the value of transactions that occur through BB Agent has not encouraged the creation demand for credit as expected from the program. In other words, the increase of transaction value in BB program has not succeeded in creating the financial system (saving and credit) in rural area as expected by Financial Inclusion Strategy.

\subsection{Simulation-2: The impact of an increase in investment}

The increased in investment is based on the objectives of the Financial Inclusion Strategy to increase the production and income of the society of the program targets. In addition, the households' micro and small business have the potential to be developed. The data of net expansion of credits of micro, small, and medium enterprises (MSMEs) explains that the growth of credit of micro-enterprises in one year, from October 2015 to October 2016 is $18 \%$ (from 14.03 trillion rupiah to 17.18 trillion rupiah) (BI, 2016). Therefore, the scenario to increase the investment by $20 \%$ for micro-small business households in rural areas which are considered 'underbanked people' is relevant. The result of simulation is presented in Table 7.

The results show that the increase in investment has the greatest impact on credit (CR) and business size (SU) with positive signs. This result is consistent with the prediction that to increase investment, the business needs credits (Derosari, 2014), which may come from family, relatives, bank loans, or borrowing from money-lenders. Furthermore, the credit increases the size of their business, as well as the production (Q), marketed surplus (MS), profit (PFIT), and disposable income (YD). However, the impact of increases in investment on savings (SAV) is only small. Simulation results show that an increase in investment (INV) of $20 \%$ increases business profit (PFIT) by $1.36 \%$, but an increase in savings (SAV) is only $0.10 \%$. This illustrates that saving behavior from micro and small business household is still low. 
Table 7. The impact of an increase in investment (INV)

\begin{tabular}{|c|c|c|}
\hline \multirow{2}{*}{ Endogen Variable } & \multicolumn{2}{|c|}{$20 \%$ INV } \\
\hline & Value Change & $\%$ Change \\
\hline 1. Production $(\mathrm{Q})$ & $1,290,000$ & 0.46 \\
\hline 2. $\quad$ Investment (INV) & - & - \\
\hline 3. $\quad$ Family Labor (TKK) & 0.50 & 0.07 \\
\hline 4. Non-Family Labor (TKL) & 1.20 & 0.35 \\
\hline 5. $\quad$ Total Labor (TK) & 1.70 & 0.16 \\
\hline 6. $\quad$ Marketed Surplus (MS) & $1,320,000$ & 0.47 \\
\hline 7. $\quad$ Business Size (SU) & $16,520,000$ & 4.47 \\
\hline 8. $\quad$ Total Revenue of Production (TRQ) & $1,290,000$ & 0.46 \\
\hline 9. $\quad$ Profit (PFIT) & $1,295,462$ & 1.36 \\
\hline 10. Total Revenue of BB Households (PRTBB) & $1,290,000$ & 1.14 \\
\hline 11. Disposable Income (YD) & $1,300,000$ & 1.21 \\
\hline 12. Total Consumption (TCONS) & 60,595 & 0.23 \\
\hline 13. Food Consumption (CCPG) & 64,800 & 0.46 \\
\hline 14. Non-Food Consumption (CCNPG) & $(4,206)$ & -0.03 \\
\hline 15. HR Investment (ISDM) & 1,334 & 0.03 \\
\hline 16. Saving (SAV) & 23,884 & 0.10 \\
\hline 17. Credit (CR) & $4,880,000$ & 3.04 \\
\hline
\end{tabular}

Source: Own compilation

Despite small impacts, the simulation results show that increasing the capacity of the micro and small business households in the rural potentially increase the demand for credit and has a positive impact on their welfare as expected to occur in accordance with the objectives of Inclusive Financial Strategy (BI, 2014).

\subsection{Simulation-3: The impact of an increase in transaction value and investment}

A scenario of a combination of an increase in investment and value of the transaction by $20 \%$ and $100 \%$ respectively is presented in Table 8 . The simulation results show the combination increased in investment and transaction value, produce a positive impact on all endogenous variables with a greater percentage change than the previous two simulations. However, in general the amount of changes produced is still low as well as simulation of investment changes. This condition is in line with the characteristic of micro-small businesses which are traditional and not entirely commercial-oriented, indicated by the type and size of the business that is relatively fixed for long periods of time.

The results explain that the development of BB program, namely an increase in transaction value has a greater impact on production activity and business household welfare when combined with the increase in their capacity business, i.e. increase in investment. The impact on increase in non-food consumption remains dominant. The impact of an increase in transaction value to the increase of non-food consumption is similar to that described in the first simulation, that the presence of $\mathrm{BB}$ agents in rural areas is usually for transactions related to the payment of electricity, purchase of pre-paid electricity vouchers and top-up of cell phone credit, transfer of credit instalments, other online payments, as well as remittances to families in different places. 
Table 8. The impact of an increase in transaction value and investment

\begin{tabular}{|c|c|c|}
\hline \multirow{2}{*}{ Endogenous Variable } & \multicolumn{2}{|c|}{$20 \%$ INV \& 100\% TRSNIL } \\
\hline & Value Change & $\%$ Change \\
\hline 1. Production $(\mathrm{Q})$ & $2,900,000$ & 1.03 \\
\hline 2. $\quad$ Investment (INV) & -- & $-\overline{-}$ \\
\hline 3. $\quad$ Family Labor (TKK) & 1.10 & 0.15 \\
\hline 4. Non-Family Labor (TKL) & 2.60 & 0.77 \\
\hline 5. $\quad$ Total Labor (TK) & 3.70 & 0.35 \\
\hline 6. $\quad$ Marketed Surplus (MS) & $2,920,000$ & 1.05 \\
\hline 7. $\quad$ Business Size $(\mathrm{SU})$ & $16,750,000$ & 4.53 \\
\hline 8. Total Revenue of Production (TRQ) & $2,900,000$ & 1.03 \\
\hline 9. $\quad$ Profit (PFIT) & $2,901,096$ & 3.04 \\
\hline 10. Total Revenue of BB Households (PRTBB) & $2,900,000$ & 2.57 \\
\hline 11. Disposable Income (YD) & $2,910,000$ & 2.70 \\
\hline 12. Total Consumption (TCONS) & $1,396,249$ & 5.28 \\
\hline 13. Food Consumption (CCPG) & 145,116 & 1.03 \\
\hline 14. Non-Food Consumption (CCNPG) & $1,251,132$ & 10.13 \\
\hline 15. HR Investment (ISDM) & 2,987 & 0.06 \\
\hline 16. $\quad$ Saving $(\mathrm{SAV})$ & 53,488 & 0.22 \\
\hline 17. Credit (CR) & $5,050,000$ & 3.15 \\
\hline
\end{tabular}

\section{Source: Own compilation}

When the increase in value of transactions results in a negative impact on investment and credit, then the increase in transaction value which is combined with the increase in investment yields a positive impact.On the other hand, its impact on production value (Q), business profit (PFIT), and disposable income (YD) is twice higher than that of the two previous simulations. Therefore, it can be concluded that the development of the BB program will results in greater impact when undertaken in conjunction with other programs that increase the business capacity of the program target group. However, the three simulations shows that saving transactions (SAV) only have a small impact. This condition shows that saving behavior from micro and small business households is still very low. The existence of a BB Agent that is close to the place of business in the countryside has not been able to encourage the creation of savings transactions. The results of all three simulations are shown on the Graph 1.

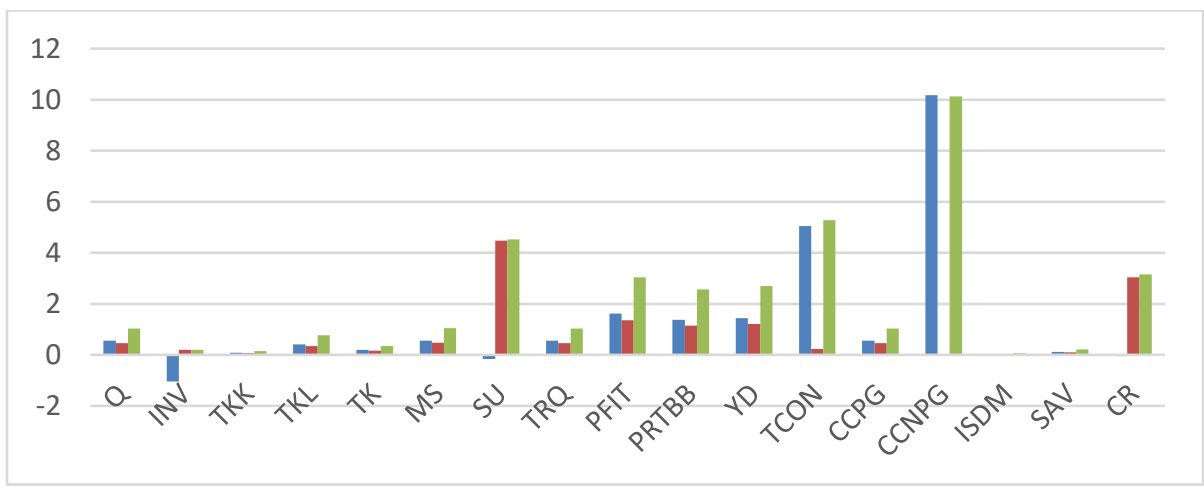

Graph 1. The impact of transaction value, investment, and both on the endogen variables Source: Own data 


\section{Discussion}

Simulation results indicate that the value of transaction that occurs in the BB program in rural areas are more related to non-food consumption expenditure. The results are in line with the portrait of program implementation, in which, types of transactions conducted by households at $\mathrm{BB}$ agents are more related to non-food consumption expenditure, namely transactions for electricity payment, purchase of mobile phone credit, and money transfer to the family in different places. This indicates that the existence of the program still has a role in the activity of payment transactions and by using cash money (cash payment transaction). The results also illustrate that the implementation of the BB program, which is expected to affect the production activities in rural areas through savings transactions and cash withdrawal through BB agents, still far from expected. The results are in line with the study by Untoro et al. (2014) who found that sustainable efforts are needed for the society in rural areas to be willing to use digital financial services.

The result also shows that the development of the BB program which is approximated by value of transaction encourages production through consumption expenditure, but does not affect the development of business capacity. The increase in the value of transactions that occurs through BB Agent has not encouraged the demand for credit as expected from the program. The results are not in line with the expected goal in the BB program, that through the ease of financial transactions that occur in the branchless banking program, the economic growth of the society will occur. Customers are expected to be able to plan the production and investment activities that are feasible, obtain returns and income, and manage their household consumption expenditure. Besides, customers can be involved in financial transactions and utilize the funding facilities such as credit, savings, and conducting other financial transactions. The results are different from the statements of Sanjaya (2014) and Jain (2015) who affirmed that equitable distribution of financial services will create new and rapid sources of economic growth, thus creating a more equitable growth.

The simulation results in the form of an increase in the number of transactions coupled with an increase in investment provide two times higher increase in production and income than the simulation results carried out partially. This illustrates that the government as the program owner, in order to achieve the objectives in the inclusion financial strategy, namely increasing production capacity of the program targets, the BB program needs to be accompanied by other programs that can increase the capacity of the business carried out by the society, especially micro-small enterprises.

The low of the effect on savings in the three simulation models shows that the utilization of limited banking services available to the households in remote areas has not led to an increase in savings. This shows that the existing of BB agents close to the society in remote areas are not related yet to the savings behaviour of the MSE business actors. They used more of those facilities for payment transactions. Some respondents explained that they were not sure yet with the savings system through an agent. It implies the need for further analysis regarding the factors that prevent micro-small business actors in rural areas to save their money through BB agents.

\section{Conclusion}

The low level of financial transaction carried out by micro and small business households in rural areas shows that the financial services provided by BB agent have not been sought by the target group, namely productive poor people. Therefore, the government as the program owner needs to increase the involvement of the target group through socialization and education. 
The increase in the value of transactions that occurs through BB Agent has not encouraged the demand for credit as expected from the program. This implies that the increase of transaction value in BB program has not succeeded in creating the financial system as it was hoped to achieve the goals of the Financial Inclusion Strategy.

To achieve the objectives of the Financial Inclusion Strategy, i.e. to encourage economic growth by creating a financial system that can be accessed by all levels of society, must be accompanied by another program that increases the business capacity of the target groups.

Further analysis is needed to find out the factors that hinder the community, especially micro-small business actors to increase saving transactions through agents. On the other hand, this research does not analyze the implementation of the BB program on household business units that have not been involved in the program. Therefore, it suggests to further research to analyze the behavior of business households around the BB Agent that are not yet involved in the program.

\section{Acknowledgement}

This work was supported by Universitas Kristen Indonesia in the framework of dissertation research. We also would like to thank Bank BRI - Indonesia, which has supported, especially in obtaining the data related to Branchless Banking agents. Thanks also to Mr. Karam Singh as English language proofreader of this manuscript.

\section{References}

Aduda, J., \& Kalunda, E. (2012). Financial inclusion and financial sector stability with reference to Kenya: A review of literature. Journal of Applied Finance and Banking, 2(6), 95.

Bagi, F. S., \& Singh, I. J. (1974). A Microeconomic Model fo Farm Decisions in an LDC: A Simultaneous Equation Approach.

Bank Indonesia. (2014). Booklet Keuangan Inklusif Bank Indonesia. [Internet]. [2014 September 25]. Retrieved from: http://www.bi.go.id/id/perbankan/keuanganinklusif/ edukasi/ Contents.

Bank Indonesia. (2016). Net expansion of micro, small, and medium enterprises (MSMEs) credits. [Internet]. Retrieved from: http://www.bi.go.id/ id/ umkm/kredit/data/ Documents/ Perkembangan\%20 Kredit\%20 UMKM \%20dan\% 20MKM\% 20Okt\%202016_NE.pdf

Chuchuen, C. (2016). The Perception of Mobile Banking Adoption: The Study of Behavioral, Security, and Trust in Thailand. International Journal of Social Science and Humanity, 6(7), 547.

Davidson, N. (2011). Mapping and Effectively Structuring Operator-Bank Relationships to Offer Mobile Money for the Unbanked [Mobile Money for the Unbanked]. London, England: GSM Association.

Demirguc-Kunt, A., \& Levine, R. (2008). Finance, financial sector policies, and long-run growth. The World Bank.

Derosari, B. B. (2014). Pengaruh kredit dan bantuan modal pada perilaku ekonomi dan kesejahteraan rumahtangga tani di Provinsi Nusa Tenggara Timur [Disertasi].[Bogor (ID)]: Institut Pertanian Bogor (Doctoral dissertation, Tesis. Sekolah Pascasarjana, Institut Pertanian Bogor, Bogor). 
Frani, O. (2017). Dampak Branchless Banking Sebagai Strategi Inklusi Keuangan Terhadap Tingkat Kompetisi Industri Perbankan Indonesia (Studi Kasus Bank Buku 4). Jurnal Ilmiah Mahasiswa FEB, 5(2).

Heatubun, A. B., \& Sinaga, B. M. (2001). Pemberdayaan dan Kegiatan Petani Multikomoditi di Pedesaan Propinsi Maluku: suatu Kajian Ekonomi Rumahtangga. Soca (SocioEconomic of Agriculturre and Agribusiness).

Ivatury, G., \& Mas, I. (2008). The Early Experience with Branchless Banking. Focus Note 46. Washington, D.C.: CGAP

Jain, C. S. (2015). A Study of Banking Sector's Initiatives Towards Financial Inclusion in India. Journal of Commerce and Management Thought, 6(1), 55.

Khanan, P. (2016). Aspek yuridis keberadaan agen dalam model branchless banking di sistem perbankan Indonesia. Jurnal Privat Law IV (1):13-20.

Koutsoyiannis, A. (1977). Theory of econometrics; an introductory exposition of econometric methods(No. 04; HB141, K6 1977.).

Mas, I. (2009). The economics of branchless banking. Innovations, 4, 57-75.

McKay, C., \& Pickens, M. (2010). Branchless banking 2010: Who's served? At what price? What's next? (Vol. 66). CGAP Focus Note.

Montazemi, A. R., \& Qahri-Saremi, H. (2015). Factors affecting adoption of online banking: A meta-analytic structural equation modeling study. Information \& Management, 52(2), 210-226.

Otoritas Jasa Keuangan. (2015). Laporan Kinerja OJK 2015. [10 April 2016]. Retrived from: http://www.ojk.go.id/id/berita-dan-kegiatan/publikasi/Documents/Pages/laporankinerja-ojk-2015/FA_Laporan kinerjaOJK2015rev070116_II.PDF.

Otoritas Jasa Keuangan. (2016). Laporan Kinerja OJK 2016. [Internet]. [10 April 2017]. Retrived from: https://www.ojk.go.id/id/data-dan-statistik/laporankinerja/Documents/Laporan\%20Kinerja\%20OJK\%202016.pdf

Permadi, A.D. (2017). Persepsi masyarakat desa pendem berbah terhadap teknologi branchless banking. [mini thesis]. Yogyakarta (ID): Universitas Negeri Yogyakarta.

Phonthanukitithaworn, C., Sellitto, C., \& Fong, M. (2015). User intentions to adopt mobile payment services: A study of early adopters in Thailand. Journal of Internet Banking and Commerce, 20(1).

Sanjaya, I. M. (2014). Inklusi Keuangan Dan Pertumbuhan Inklusif Sebagai Strategi Pengentasan Kemiskinan Di Indonesia (Doctoral dissertation, Tesis).

Secioktaviany, Z. A., \& Asrori, H. (2016). Optimalisasi Manajemen Risiko Sebagai Upaya Preventif Risiko Hukum Pada Bank Penyelenggara branchless Banking Di Indonesia. Privat Law, 4(2).

Shadikin, R. (2017). Tinjauan maqashid asy-syari'ah terhadap sistem keamanan perbankan pada program branchless banking. [Mini Thesis]. Yogyakarta (ID): UIN Sunan Kalijaga Yogyakarta.

Shaikh, A. A., \& Karjaluoto, H. (2015). Mobile banking adoption: A literature review. Telematics and Informatics, 32(1), 129-142.

Siddik, M. N. A., Sun, G., Yanjuan, C. U. I., \& Kabiraj, S. (2014). Financial Inclusion through Mobile Banking: A Case of Bangladesh. Journal of Applied Finance and Banking, 4(6), 109.

Sinaga, B.M. (2011). Ekonometrika Lanjut. Bogor (ID): Bogor Agricultural University.

Untoro, Widodo, P.R., Yuwono, W., Dewi, K., Christina, R. (2014). Layanan keuangan digital; hambatan dan faktor-faktor penentu keberhasilan. Working Paper. Jakarta (ID): Bank Indonesia.

Wahid, F., \& Iswari, L. (2007). Adopsi teknologi informasi oleh usaha kecil dan menengah di Indonesia. Jurnal Inovasi dan Kewirausahaan. 
The World Bank. (2015). Global Financial Development Report 2014. [Internet][2015 Juni 25]. Retrieved from: http://econ.worldbank.org/

Wibowo, P. W. (2013). Branchless Banking Setelah Multilicense: Ancaman atau Kesempatan Bagi Perbankan Nasional. Bank Indonesia, Jakarta.

Willis, R., Marshall, J. N., \& Richardson, R. (2001). The impact of 'branchless banking'on building society branch networks. Environment and Planning A, 33(8), 1371-1384.

Yuwono, M. (2017). Strategi penigkatan minat petani menggunakan produk dan jasa keuangan formal dalam rangka keuangan inklusif [dissertation] Bogor (ID): Institut Pertanian Bogor. 


\section{Appendix}

Definition of the variables

\begin{tabular}{|c|c|c|c|}
\hline $\begin{array}{l}\text { Name of } \\
\text { Variable }\end{array}$ & $\begin{array}{l}\text { Definition of Variable } \\
\text { (value per year) }\end{array}$ & $\begin{array}{l}\text { Type of } \\
\text { Variable }\end{array}$ & $\begin{array}{l}\text { Type of } \\
\text { Equation }\end{array}$ \\
\hline $\mathrm{Q}$ & $\begin{array}{l}\text { Value of production of one of the main business of } \\
\text { the household business (Rp) }\end{array}$ & Endogenous & Structural \\
\hline INV & Investment of the main business (Rp) & Endogenous & Structural \\
\hline $\mathrm{P}$ & Average Price of output (Rp/unit) & Exogenous & $*$ \\
\hline VCOST & Variabel cost: Raw material costs (Rp) & Exogenous & $*$ \\
\hline FCOST & $\begin{array}{l}\text { Fixed cost: the rent value of business place and } \\
\text { depreciation value of fixed goods (Rp) }\end{array}$ & Exogenous & $*$ \\
\hline SU & $\begin{array}{l}\text { Business size: the value of production plus the value } \\
\text { of the main assets that have been depreciated ( } R p)\end{array}$ & Endogenous & Structural \\
\hline SAV & Households saving $(\mathrm{Rp})$ & Endogenous & Structural \\
\hline TKK & Family labor used in the main business (man days) & Endogenous & Structural \\
\hline TKL & $\begin{array}{l}\text { Non-family labor used in the main business used } \\
\text { (man days) }\end{array}$ & Endogenous & Structural \\
\hline TK & Total labor used in the main business (man days) & Endogenous & Identity \\
\hline AKK & Family workforce (no. of person) & Exogenous & $*$ \\
\hline $\mathrm{W}$ & Wage rate $(\mathrm{Rp} / \mathrm{month})$ & Exogenous & $*$ \\
\hline MS & $\begin{array}{l}\text { Marketed surplus: the value of production sold in the } \\
\text { market (Rp) }\end{array}$ & Endogenous & Structural \\
\hline TRQ & Total revenue production $(\mathrm{Rp})$ & Endogenous & Identity \\
\hline PFIT & Profit of the business(Rp) & Endogenous & Identity \\
\hline PLL & $\begin{array}{l}\text { Other income from another activity or another } \\
\text { household member income (Rp) }\end{array}$ & Exogenous & $*$ \\
\hline PRTBB & Total household income (Rp) & Endogenous & Identity \\
\hline YD & Disposable income: Income after tax $(\mathrm{Rp})$ & Endogenous & Identity \\
\hline $\mathrm{CS}$ & $\begin{array}{l}\text { Subsisten consumption: the consumption value from } \\
\text { the production }(\mathrm{Rp})\end{array}$ & Exogenous & $*$ \\
\hline TAX & Tax and other fixed contributions (Rp) & Exogenous & $*$ \\
\hline $\mathrm{CCPG}$ & Food consumption expenditure $(\mathrm{Rp})$ & Endogenous & Structural \\
\hline CCNPG & Non-food consumption expenditure (Rp) & Endogenous & Structural \\
\hline TCONS & Total consumption expenditure $(\mathrm{Rp})$ & Endogenous & Identity \\
\hline ISDM & $\begin{array}{l}\text { Investment of human resources: education and } \\
\text { health investment (Rp) }\end{array}$ & Endogenous & Structural \\
\hline INVPEN & Investment for education of the children (Rp) & Exogenous & $*$ \\
\hline UK & Family size (no. of person) & Exogenous & $*$ \\
\hline AS & Number of school children (no. of person) & Exogenous & $*$ \\
\hline $\mathrm{Cr}$ & $\begin{array}{l}\text { Credit: the total amount of credit taken by the } \\
\text { households (Rp) }\end{array}$ & Endogenous & Structural \\
\hline $\mathrm{R}$ & Interest rate $(\% /$ year $)$ & & \\
\hline TRSNIL & $\begin{array}{l}\text { Total value of transaction of the households at BB } \\
\text { agents (Rp) }\end{array}$ & Endogenous & Structural \\
\hline
\end{tabular}

